\title{
Comparative Analysis of the HRM Practices between Hospitality and Healthcare Sectors in South Kerala
}

\author{
R. Prakash Pillai ${ }^{* *}$ and Christy Abraham² \\ ${ }^{1}$ Head, PG Department of Personnel Management, Loyola College of Social Sciences, Thiruvananthapuram, \\ Kerala, India \\ ${ }^{2}$ Research Scholar, Faculty of Management Studies, University of Kerala, Thiruvananthapuram, Kerala, India
}

\begin{abstract}
Hospitality and health care sectors have similarities due to service oriented and customer centric approach. The study is aimed to identify and understand the link between hospitality and health care sectors in terms of human resource management practices and how it enriches the business activities. The study is qualitative in nature and a case study was used. Purposive sampling method was used and primary data was collected through direct observation and semi-structured interviews with experts of the five star hotels and super specialty hospitals in South Kerala and secondary data was collected from journals, newspapers, books and internet, etc. Study analyzed that hospitality sector is having well functioned and polished HRM practices compared to health care sector. Each HRM practice is inter-connected and resulted into lower exit rate and better satisfaction of the staff. Proper execution of human resource management practices such as recruitment, selection, induction, training \& development, performance appraisal, compensation, employee welfare, grievance mechanism and exit management has a significant role in satisfaction of the employees and performance of the organization. Well functioned HR department and HRM practices will enhance the effectiveness of the staff and that ultimately lead to the best quality service delivery.
\end{abstract}

Keywords: Hospitality, Health Care, Human Resource ManagementPractices, Service Sector, HR Department, Service Delivery

\section{Introduction}

The terms hospitality and health care initially may seem to be entirely different, but there are lot of similarities. Both are dealing with tangible and the intangible aspects. That is the challenge as well as the attraction of these two sectors. Both the industries have seen significant changes such as the steady growth of budget hotels, boutique hotels, coffee houses, restaurants, multi national chains, secondary, tertiary and quaternary health care institutions in key cities and Primary Healthcare Centers (PHCs) in rural areas. Nowadays the essence of service parameters of these sectors is contributing each other to succeed the minds of the customers- king of the business. This study is mainly concentrated to understand the link between these two sectors in terms of their Human Resource Management Practices. It considers the functioning of hospitality and healthcare sector and how the human resource management practices enriches the business activities. Lot of studies have been conducted to analyze the HRM practices in these two sectors especially in developed countries and some studies in India also. But the Kerala perspective is a missing one and that is the need for this paper. Effective human resource management practice in the service industry is very

*Email: prakashpillair@gmail.com 
important, because the key of the success is in the hands of the employees.

\section{Objectives}

- To identify the Human Resource Management practices in the hospitality and health care sector

- To do an inter and intra-sector analysis of Human Resource Management practices

\section{Literature Review}

Since mid 1980s, Human Resource Management has gained acceptance in academic and industrial world. Desseler (2007) defines Human Resource Management as the policies and practices involved in carrying out the human resource aspects of a management position including human resource planning, job analysis, recruitment, selection, orientation, compensation, performance appraisal, training and development, and labor relations. Effective management of human resources is essential for the overall growth of organization and it's undertaken by small managers in small business and by HR manager in big companies or organizations (Boella \&Turner, 2013). Stavrou, Charalambous and Spiliotis (2007) in their study, through Kohonen's Self Organizing Map, identified that better utilization of HRM as a tool for increasing competitiveness inthe private sector and service quality as well as productivity in the public sector, as well as improving the working conditions of work-forces of all grades in the European Union, Griffiths, Maben and Murrells (2011) studied 8409 English general practices in UK and analyzed that the strongest predictors of quality of clinical care were organizational factors of education, training and use of patient experience surveys and not staffing level which indicated that the benefits and importance of education, training and personal development of nursing and other practice staff was very evident. Delaney and Huselid (1996) pointed out that progressive HRM practices, including selectivity in staffing, training, and incentive compensation, are positively related to perceptual measures of organizational performance in their study in for-profit and nonprofit firms from the National Organizations Survey, USA.
In their study of 5 hospitals in the northeast United States Wheeler, Halbesleben and Harris (2012) concluded that efficient HRM systems is a best way to reduce employee turnover intentions and improve the productivity of the firm. Hsu et al. (2007) in their study in Taiwan nursing homes identified the factors related to higher work stress included working in a hospital-based nursing home, having a fixed schedule, night work, feeling burden, inconvenient facility, less enthusiasm, and self-rated higher stress and they pointed out that work stress for care attendants is related to human resource management and potential management strategies can alleviate work stress for those workers. Riaz, Ayaz, Wain, and Sajid (2010) in their study of Pakistani hospitals selected human resource management practices such as performance evaluation, promotion, compensation and they analyzed that there is a positive association between promotion practices and compensation practices with employee performance but employee performance is not significantly associated with performance evaluation. Pakistani hospitals need to change some compensation practices for the improvement of hospital employee's performance and hence the growth of the organization. In their study conducted in a hospital in Noida, Tomar and Dhiman (2013) pointed out that healthcare organizations had a significant change since the past decade and the efficient management of HR function is essential for improving and upholding service delivery in hospitals and HR specific issues such as standardization of nursing activities, appraisal systems, effective communication channels, and compensation structure, all affect the quality of service provided in a hospital. According to Swaminathan and Gowrishankar (2010), the implementation and functioning of HR policies such as team work, employee empowerment, leadership, communication level are statistically higher than the bench mark level, but the mean scores of recognition, decision making, and training \& development are lower than the international standard value in the case of private hospitals in Mayiladuthurai Town and it's a concern for the management for success. So the effective functioning of human resource management practices is very crucial for the health care organizations for its survival and overall development. 
The hospitality industry, with its high dependence on a workforce that is capable of delivering the promise of a quality product and service, must embrace the principles that highlight the concept ofhuman resource management (Boella \& Turner, 2013). In a study conducted for hotel staff in Singapore, Nankervis and Debrah (1995) summarized that human resources play an important role in the success of organizations to achieve its objectives. A study conducted by Berger and Ghei (1995), on a facet of hospitality hiring, pointed out that the success of the hotel industry depends on the quality of its employees and their effective management in order to assist the organization to achieve its objectives. In his study, Huioyang (2007) analyzed the role of human resource management practices such as recruitment, selection, orientation, training and development, performance appraisal, exit management and found out that HRM has a key role in the development and retaining of competitive advantage in organizations and the human resource managers have a valuable role to play in the executive management teams of hotels. Hayes and Ninemeier (2009) said that hospitality managers should be well versed in HR management, including employee recruitment and selection, training, compensation, performance appraisal and discipline, safety, and other key areas in which they would be personally called upon to make critical decisions. Chauhan and Patel (2014) identified the positive impact of effective recruitment, selection, carrier growth and working condition of the employees of hotels in Udaipur division on their satisfaction level and revealed role of these human resource practices.

According to Zygourakis et al. (2014) there are many similarities between hospitals and hotels, the foremost being the focus on guests/patients who obtain lodging and services, employee selection and training,warm welcome to the guests/patients by employees, anticipation of needs by staff and using technology to support a culture of service. Both sectors employ a large hierarchy of workers with varying levels of responsibility. Employees are the most capable of influencing the customer experience. A primary goal should therefore be to serve employees well, so that patients will be wellserved in turn.

\section{Background of the Study}

Healthcare industry includes hospitals, medical devices, clinical trials, outsourcing, telemedicine, medical tourism, health insurance and medical equipment. Public healthcare system is concentrating on the rural and poor people, while private system mainly concentrating on the urban category. Based on the India Brand Equity Foundation's market research the overall Indian health care market today is US\$ 65 billion, of which the hospital supplies and health care equipment segment is believed to be only around US\$ 4.5-5 million. Health care delivery, which includes hospitals, nursing homes and diagnostics centers, and pharmaceuticals, constitutes 65 per cent of the overall market. The hospital and diagnostic centers attracted foreign direct investment worth US\$2,793.72 million between April 2000 and January 2015, according to data released by the Department of Industrial Policy and Promotion (DIPP). The demand for better quality hospital services has been consistently elevated in India. Apollo Hospitals Enterprise Ltd., CARE Hospitals Group , Max healthcare, Fortis Healthcare Ltd, Aravind Eye Hospitals are some of the leading players in the hospital industry.

The backbone of the hospitality sector is customer oriented service through effective management of human resources. Hospitality sector is booming, revenue generating and employment creating service industries in India. The tourism and hospitality sector is among the top 15 sectors in India to attract the highest Foreign Direct Investment (FDI). During the period April 2000-February 2015, this sector attracted around US\$ $7,862.08$ million of FDI, according to the data released by Department of Industrial Policy and Promotion (DIPP). Based on the India Brand Equity Foundation's market researchthe growth rate in Foreign Exchange Earnings (FEEs) in rupee terms in December 2014 over December 2013 was 7.3 per cent. The inflow of medical tourists is expected to cross 320 million by 2015 compared with 85 million in 2012 according to a joint report by FICCI and KPMG. The government of India is taking lot of initiatives such as policy formulations and modifications, strategy development concentrating on the development of hospitality sector and the launch of several branding and marketing initiatives such as Incredible India! and Athiti Devo 
Bhava etc. Indian companies leading in the hospitality sector include Asia Hotels, ITC, East India Hotels (EIH), Bharat Hotels, etc.

\section{Methodology}

This research is qualitative in nature and a case study was used to get an in- depth understanding of the human resource management practices in the hospitality and health care sectors. The study mainly concentrated on the South Kerala. Two 5-star hotels and two super specialty hospitals were taken for the study to balance the quality of their performance and service delivery. Both the hotels were marketed as an Upper Upscale Brand. Two super specialty hospitals were taken for the study based on their accreditation aspects. In order to maintain the confidentiality, hotels were termed as hotel 1 and hotel 2 and hospitals were termed as hospital 1 and hospital 2. Purposive sampling method was used to select top management people, HR managers and HR executives of the organization. Primary data was collected through semi-structured interviews with experts which included openendedquestions. Direct observation was also involved in the research as a method of data collection. The secondary data have been collected from related journals, books, newspaper and internet.

\section{Findings}

HRM practices are essential components of the service sector because people work better and provide better care when they are happy. Researcher is trying to explore and analyze HRM related practices in the 5 star hotels as well as super-specialty hospitals.

\subsection{Manpower}

Both the hotels are having permanent and outsourced employees. Hotels are having 204 and 110 employees respectively. Hospitality sector is having some affinity towards male staff; even though hotel's top officials are saying that it's because of the government regulation related to the female's late night duty. The hotels are having large employee- guest ratio. Both these aspects are entirely different in the case of healthcare sector. Hospitals are having 900 and 400 employees respectively. Most of the employees in the health care sector are females and the employee - patient ratio is very low. So mainly nurses are forced to attend several patients at a time and it affects the employee productivity and also de-motivates the employee.

\subsection{Managerial Support}

Hotels are providing more freedom and flexibility to the HR managers in decision making. Individual freedom and delegation of authority motivate HR team to deliver the maximum output. Hotel 1 is a subsidiary of a leading company in the hospitality sector. So the processes are having an international touch and a more polished form which is absent in the case of hotel 2 . But still the later is also trying to improve its performance by formulating new policies. In the case of hospitals, the HR manager needs to consult with the top management in decision making. Both the hospitals are not a part of any big company in the health care sector and it makes difference in the case of managerial and HR related policies and activities. Managerial support, operational freedom, strong ancestral base are important factors in the case of service excellence.

\subsection{HR Department}

Hotels have a well functioned HR department includes HR manager and HR executives. Each day starts with department meeting, followed by a review meeting between the HR manager and the general manager to discuss future plans and past performances. Hotel 1 has a highly experienced HR manager, but hotel 2 is lacking that. So the second person is trying her level best to increase the productivity by proper consultation with her subordinates to understand the hospitality related jargons and process. But when the hotels are compared with the hospitals, the functioning of HR department is marvelous. The role of HR manager is strategic in nature. The hotel 1 is a part of an international brand and they are having innovative and excellent planning and implementation of HRM process and they are co-coordinating the CSR activities of the firm. Hotel 2 is a beginner in the hospitality sector. In order to get the public and talented candidate's attention they are trying to incorporate strategic decisions. Hospitals are mainly concentrating on the accreditation related requirements. The communication system and channels are not fully established in 
the hospital 1 even though they are having HR director, HR manager and 1 HR executive. It's a serious issue which affects the effectiveness of the HR department. In the case of hospital 2, HR manager used to consult her superiors in each stage of decision making. The HR manager of the hospitals is acting as the executor of the already established routine activities. Effective HR team with proper co-ordination and communication finally results into employee co-ordination which is evident in the hospitality sector compared to health care sector.

\subsection{HRM Practices}

HRM practices are applicable to each employee in the hospitality sector from top to bottom. But in the case of health care sector, the policies and decisions are mainly for the lower level employees such as nurses and other para-medical staff. Doctors are having more freedom to negotiate with the top management. Researcher focused on the human resource management practices such as recruitment, selection, induction, training \& development, performance appraisal, compensation, employee welfare, grievance mechanism and exit management.

\subsubsection{Recruitment}

Hotels use different recruitment sources to get efficient candidates. Hotels depend on websites, agencies, employee references, employee transfers, promotions and campuses across India. Hotel 1 is taking fresher to provide on the job training and they are termed as 'buds'. Hotel 2 is providing internship facility to the students during their course. If the student is competent enough, he will become an employee. HR executive said that such activity creates more commitment from the employee, because the organization should have a major role in the employee's career in the initial stage itself. Hospitals are having less number of recruitment sources due to large number of applicants. Hospital 1 advertises through websites, while hospital 2 has newspaper advertisements, websites, E mails to HR department, employee referrals, direct entry to the hospitals etc. Hospital 1 is claiming that they have a good reputation in the market so the need for excessive advertisement is very low due to large number of applicants.

\subsubsection{Selection}

In the hospitality sector, both the hotels are following almost similar practices. After identifying the vacancy, HR department places an advertisement. The screening of resume and the reference checking will bedone followed by an interview with the HR manager and the concerned department head. Successful candidate will be interviewed by the general manger and finally the employee will be selected based on his performance in all the rounds. Trial test is carried out for the production department candidates and it's having the greatest priority. After the medical examination, candidate becomes the employee and completes all joining formalities. The probation period of the employee in the hotel 1 is 6 months and in hotel 2 its 1 year for senior level employee and 6 months for lower level employee. In health care sector, doctors and nurses are having different selection criteria. In hospital 1, for the selection of nurses, the stages are resume screening, written test, interview with nursing co-coordinator and HR manager and approval by chairman. Interview of junior doctors is done by chairman and superintendent, and senior doctors by chairman and MD. In the hospital 2, for the nurses, the stages are resume screening, written test, interview with GM and HR managerand CEO. But for the doctors, it's screening of the resumes and interview with MD. In health care sector, at the time of selection itself company is indirectly communicating the positions and roles of the employees. The hospitality sector is treating the employees in similar manner, because they believe that even the lower level employee is an essential part of the company.

\subsubsection{Induction, Training \& Development}

Hotel 1 has 3 days induction program which includes common classes, meeting with the head of the departments etc. But the hotel 2 has only 3 hours of induction program- 2hours common class and 1 hour department familiarization and it is compensated by their monthly training. In hotel 2 each employee must have 2.1 training hour/ week and 300 training hours in a department/ month. Hotel 2 has on the job training and demo classes. Hotel 1 has extensive training programs. They are sending their employees to other branches of the parent company for cross exposure training based on their years of experience, conducting separate workshops for 
employees, cross functional trainings between various departments etc. Years of experience in the hospitality sector and the position of subsidiary of a large hotel chain helps the hotel 1 to arrange more effective training programs for their employees and to improve their service quality. Both the hospitals are not providing any kind of induction programs to the doctors. Hospital 1 provides 2 weeks induction programs to nurses and 4 days induction programs to the paramedical staff. A nurse is getting around 4-5 training programs per year especially during the introduction of new machineries or new technologie sand participating outside training programs conducted by other institutions. Hospital 1 is encouraging their doctors to attend international seminars and conferences. Hospital 2 is conducting atleast 1 training program in a month and they are arranging monetary support to their staff to attend various training programs of other institutions. Training and development programs are essential for the growth of the employees and it reflects in the organization's performance.

\subsubsection{Performance Appraisal}

Hotels have systematic performance appraisal practices compared to hospitals. Hotel 1 and hotel 2 haveannual and half yearly appraisal process respectively by immediate supervisor. Supervisor's appraisal is by HR manager and GM. In hotel 1, promotion and compensation is strictly based on performance appraisal and categories the supervisors from S5 to S1 levels and executives from E8 to E1 levels. Hotel 2 is depending on performance appraisal for compensation, promotion and training requirements. Hospital 1 is having performance appraisal once in 6 months by both the immediate supervisor and by self-appraisal. There is no appraisal process for senior doctors. Compensation and promotion etc were not based on the performance appraisal process now and they are planning to modify it. But hospital used to give warning if an employee is having very poor rating in performance appraisal. The current practice related to performance appraisal is a hindrance to the self-motivation of the employees in hospital 1. Hospital 2 doesn't have a proper performance appraisal practices till now. During the time of promotion and salary modification HR department used to discuss the past performance of the employee with concerned department head.

\subsubsection{Compensation}

In hospitality sector, employees are getting monetary as well as non-monetary benefits. Non-monetary benefits include educational support to the children, flats, travel allowance, medical support etc. HR manager of hospital 2 recollected an incident that the hotel's policy to provide medical support to its employees, by which they supported a Bengaly cook who got dengue fever on his second working day. Hotel paid all the hospital expenses. Hospitals are providing mainly monetary benefits to the employees as per government regulations. All the permanent employees and immediate family members are getting insurance coverage. They are providing very few non-monetary benefits to their employees.

\subsubsection{Grievance Redressal Mechanism}

Hotels are having an effective grievance redressal mechanism. Hotel 1 is having a separate grievance handling team, coordinated by HR manager. Likewise it is having a sexual harassment committee, welfare committee etc to address the employee related issues. If an employee suffers any problem he can directly communicate it with immediate supervisor and then to the HR manager. Hospitals are also having similar reporting system such as immediate supervisor to HR manager, to GM to MD. Both the hospitality and health care sectors concentrate on the employee's problems and the quick solutions.

\subsubsection{Welfare Measures}

Hotel 1 provides scholarships to the employees' children who secured higher grades in examinations. They are organizing picnics, sports days, parties, Joy at work program, annual days, festival celebrations etc. Hotel 1 has a peculiar system known as 'STARS'- Special Thanks and Recognition System which is an employee recognition scheme based on the positive feedback received from his guests. Based on the feedback, employee will get certain points and he will get attractive gifts and awards. On birthday, employee can have lunch at any of the outlets of the hotels with family and also on the annual day, based on the lot he may get the opportunity to stay in the hotel with family. Employees are getting casual leaves, sick leaves, privilege leaves 
and also the compensatory off. Number of voluntary retirement is almost nil in hotel 1 . Hotel 2 celebrates the annual days, festivals, special days of employees etc. Hotel 2 has two special functions such as Eva day program and Town hall meeting. The Eva day program is basically for women. On that day they can show their talents, express their view points, concerns etc to the top management and also to the HR team. Town hall meeting is like an annual day celebration and it's an open forum. On that occasion each employee can share their ideas, problems etc. Best employee and department will be selected during that program. Hotels are giving fire and safety training to the employees and they are providing gloves, masks, shoes to the employees in the production department. Hospitals celebrate annual days, festivals and provide casual leaves to the employees and the permanent staff is getting medical reimbursement. Pension is contributory in nature and for the overtime duty, staff is getting additional salary. During birth days and in the festival period employees are getting MD's gifts. Hospital 2 is having a separate fire and safety department to ensure the safety of the staff and patients. Staff union is not at all functioning in all the samples.

\subsubsection{Attrition Management and Exit Practices}

Hospitality sector has a very low rate of attrition when compared to the health care sector. The HR executive of hotel 1 said that the commitment levels of employees are very high in hospitality sector and they don't want to quit the organization. Hotel 1 has a senior cookwho retired from another outlet of the parent company, then joined in another branch and involving in the training of fresher. Hotel 1 has a business excellence model which does monthly analysis of attrition and exit. Hotel 1 has a strict exit process which starts from the initiation of resignation letter. The employee will have a discussion with concerned department head, HR manager and team which leads to the completion of employee clearance form and also the exit interview form. Employee will have 1 month notice period in staff level and 3 months' notice period in executive level. Hotel 2 is having below $5 \%$ of attrition. Both the hospitals are having similar exit process. Exit process is not very strict, because the employees are having only 1 month notice period, but in certain situation it's also flex- ible. The major reasons of exit are personal problems, opportunities in abroad, marriage etc., and some of the employees joined the concerned organization only for getting work experience from a super specialty hospital. Hospital 2 has only a 24 hours' notice period, so the employee exit is very high in hospital 2. Even though the hospitals are having higher attrition rate, they can manage the situation due to the larger number of prospective candidates.

\section{Findings and Discussion}

Hospitality sector is having well functioned HRM practices and that is evident in each activity of the company. Systematic and thoroughly monitored HRM practice's formulation and implementation will generate highly satisfied and motivated employees and that ultimately results into lower attrition rate which is less in healthcare sector. The formulation and implementation of HRM practices are not proper due to the poor functioning of HR department, lesser managerial support, improper co-ordination and communication between the team members in health care sector.

Hotels use different recruitment sources while hospitals depend on very few recruitment sources due to large number of applications. Hotel 1 has on the job training to fresher and hotel 2 has internship program to students to enhance the commitment of prospective candidates. In health care sector, employees are having series of selection process based on job role but in hospitality sector, which is not evident and they are treating the employees in almost similar manner except in the case of production department where trial test is mandatory. Hotel 1 has an extensive induction and training program which enhances the bond between the employee and the organization. Years of experience in the hospitality sector and the position of subsidiary of a large hotel chain helps the hotel 1 to arrange more effective training programs to improve their service quality. Hospitals are conducting induction program only to nurses and paramedical staff not for senior doctors. Hospital 1 is encouraging their doctors to attend international seminars and conferences and it reflects in organization's performance. Hotels have systematic performance appraisal practices 
compared to hospitals. Hospital 1 has performance appraisal for some staff, but it's not using in the case of promotion and compensation aspects. Hospital 2 does not have a proper performance appraisal practices till now. In hospitality sector, employees are getting monetary as well as non-monetary benefits but hospitals are mainly providing monetary benefits to the employees as per government regulations. Hotels are having an effective grievance redressal mechanism compared to hospitals. The presence and execution of all these HRM practices reflects in the turnover rate of the company. Hospitality sector has a very low rate of attrition and has a strict and systematic exit process compared to the health care sector .

\section{Conclusion}

Service industry, specifically the hospitality and health care sector is mainly depending on its employees for its service excellence, growth and market value. Effective HR team and HRM practices can satisfy an employee and that ultimately lead to satisfied customers, which is a core factor of service industry. The mindset of the patient is changing and he expects him to be treated just like how he is treated in the luxury hotel, especially when he is spending a premium compared to other hospitals. The healthcare industry is actually competing with this type of service industries and having an infinite growth potential in today's world. Therefore health care industry can adopt and share its management and HRM practices with such service industries in order to with stand the competition and also to improve the productivity. Hospitals are aware of the positive aspects of effective HRM practices but most of them are in paper. So the effective changes in the HRM practices and policies should be necessary and for that health care sector can consider other growing service industries.

In short the study focused on the various HR dimensions in the organizations. It considers the human resources, top management role, HR department, HRM practices in five star hotels and super specialty hospitals. Hospitality sector hasan effective HR team when compared to the health care sector. Coordination of the HR team and practices improves the overall activities of the personnel and hence the performance and growth of the hotels. In the hospitality sector itself, the brand and the number of years of performance also makes great difference in the out- put. Each HRM practice is inter-connected and resulted into lower exit rate and better satisfaction of the staff. In health care sector the HR team is having less freedom in decisions making and it's highly depending on the top management. Well functioned HR department and HRM practices will enhance the effectiveness of the staff and that ultimately lead to the best quality service delivery.

\section{Bibliography}

Berger, F., \& Ghei, A. (1995). Employment tests: A facet of hospitality hiring. Cornell Hotel and Restaurant Administration Quarterly, 36(6), 28-35.

Boella, M. J., \& Turner, S. G. (2013). Human Resource Management in the Hospitality Industry. Routledge: New York.

Carrington, D., \& Tayles, M. (2012). Intellectual capital in the Caribbean hospitality industry: Two case studies. Electronic Journal of Knowledge Management, 10(3),244-257.

Chauhan, Y. S., \& Patel, N. K. (2014). Human resources management practices and job satisfaction: A study of hotel industry. Journal of Research in Commerce \& Management, 3(9).

Delaney, J. T., \& Huselid, M. A. (1996). The Impact of Human Resource Management Practices on Perceptions of Organizational performance. The Academy of Management Journal, 39(4), 949-969.

Dessler, G. (2007). Human resource management. New Delhi: Prentice Hall of India Private Limited.

Griffiths, P., Maben, J., \& Murrells, T. (2011). Organisational quality, nurse staffing and the quality of chronic disease management in primary care: Observational study using routinely collected data. International Journal of Nursing Studies, 48, 1199-1210.

Hayes, D. K., \& Ninemeier, J. D. (2009). Human resources management in the hospitality industry. New Jersey: John Wiley \& Sons, Inc.

Hsu, H., Kung, Y., Huang, H., Ho, P., Lin, Y., \& Chen, W. (2007). Work stress among nursing home care attendants in Taiwan: A questionnaire survey. International Journal of Nursing Studies, 44, 736-746.

Huioyang, H. O. (2007). Human Resource Management in the hotel industry in Taiwan(Unpublished $\mathrm{PhD}$ thesis). Swinburne University of Technology, Australia. 
Nankervis, A. R., \& Debrah, Y. (1995). Impact of HR practices on perceived performance of hospital employees in Pakistan. Tourism Management, 16(7), 507-513.

Pugh, S. D., Dietz, J., Wiley, J. W., \& Brooks, S. M. (2002). Driving service effectiveness through employee-customer linkages. The Academy of Management Executive, 16(4), 73-84.

Rao, M., Rao, K., Shivakumar, A., Chatterjee, M., \& Sundararaman, T. (2011). India: Towards universal health coverage. Human resources for health in India. The Lancet.

Riaz, Q., Ayaz, K., Wain, A. M., \& Sajid, M. (2012). Impact of HR practices on perceived performance of hospital employees in Pakistan. Journal of Economics and Sustainable Development, 3(11), 10-16.

Sharma, V. (2010). Impact of e-recruitment on human Resource supply chain management: An empirical investigation of service Industry in Indian context. (Synopsis of the thesis for the Degree of doctor of philosophy in management).

Stavrou, E. T., Charalambous. C., \& Spiliotis, S. (2007). Human resource management and performance: A neural network analysis. European Journal of Operational Research, 181, 453-467.

Swaminathan, J., \& Gowrishankar, U. (2010). Employee engagement practices in private hospitals: A cross sectional study in Mayiladuthurai. MPRA Paper No. 39769, 1-12.

Tomar, A., \& Dhiman, A. (2013). Exploring the role of HRM in service delivery in healthcare organizations: A study of an Indian hospital. Vikalpa,38(2), 21-38.

Wheeler, A. R., Halbesleben, J. R. B., \& Harris, K. J. (2012). How job-level HRM effectiveness influences employee intent to turnover and workarounds in hospitals. Journal of Business Research, 65, 547-554.

Zygouraki, C. C., Rolston, J. D., Treadway, J., Chang, S., \& Liot M. (2014). What do hotels and hospitals have in common? How we can learn from the hotel industry to take better care of patients. Surg Neurol, 5(2), 49-53.

\section{About the Author(s)}

Dr. Prakash Pillai R. is presently Head and Asst. Professor of Department of Personnel Management at Loyola College of Social Sciences, Thiruvananthapuram, Kerala. He has around 15 years of teaching experience at PG level in different management institutes and four years of research experience. He has undertaken several research projects in the areas of Social Responsibility, Higher Education and Labour Movements for reputed Government agencies in India. He is a member of the Academic Council of the University of Kerala and a Member of PG Board of Studies in Social Work. Dr. Prakash is an approved research guide for Ph.D. in the faculty of Management Studies in the University of Kerala and Bharathiar University, Coimbatore, Tamil Nadu. He serves as a resource person for research methodology and SPSS. He has a couple of books and several research papers in his credit of publications in reputed national and international journals. Dr. Prakash is a member of AIMS (academy of Indian Management Scholars) International, Houston, USA. He is currently the Joint Secretary of 3 E Innovative Foundation, a not-forprofit organization based in Gurgaon.

Ms. Christy Abraham is a Research Scholar of University of Kerala, Trivandrum. Her research area is Human Resource Practices especially in health care sector. She has presented research papers in national and international conferences related to her area of research. 